\title{
A Study on the Teaching Transformation from Language - driven to Content - driven of College English
}

\author{
Meng Xiangyao \\ Baicheng Normal University, Baicheng, Jilin, 137000
}

\begin{abstract}
In order to cultivate high-quality academic or applied talents, the aspects of college English curriculum need to change from English for General Purposes to ESP (English for Specific Purposes). English teaching should focus on academic purposes and special needs. Therefore, the biggest challenge of college English reform is the smooth realization of college English teaching from EGP to ESP transition. In this paper, the constraints in this transition process will be analyzed to focus on coping strategies.

Key words: college English teaching; EGP; ESP; transformation
\end{abstract}

\section{Introduction}

English as an international language, has been the importance of education in China, from the beginning of the basic education of high school English courses to higher education of college English, so English can be said to run through our learning from beginning to end. Now, in our country the level as well as students' learning ability in the middle school English teaching increase a lot. Therefore, after entering the university, students have college English learning ability, especially self-learning ability. In addition, in the University, the CET4 and CET6 have a direct relationship with students' diploma so that the students pay more attention to college English. But after entering the university, we should enhance students' comprehensive ability of English, not just deal with the examination. Chinese students' English has always been considered to be "dumb English", the test scores can be high, but the ability to listen and speak can be said to be very weak. For this phenomenon, in the teaching of college English, 
how to enable students to master a more comprehensive and practical English becomes the key. The reform of college english teaching model is imperative.

From the reform and opening up, college English has gone through more than 30 years. In this process, College English is also constantly reform and innovation, in all aspects has also made some development. But a lot of data shows that China's colleges and universities generally still exist such a phenomenon, that is, college English education has the difference between English and non-English majors. Non English major is the public English course of the university, the teaching of public English mainly concentrates on the teaching of general English, but this kind of general English does not have the practicality, so it is very difficult to meet the student's study request. Another point is that the university of public English teaching hours are very small, the teacher is also a scripted and not very good training students listening and speaking ability.

Therefore, to improve the comprehensive ability of college English, we must change the teaching mode which is from language-driven to content-driven. Popular point is that to change the focus of the college English curriculum and teaching from the basic English EGP (English for General Purposes) gradually to the ESP (English for Specific Purposes) direction.

\section{The understanding of the concept of ESP}

In 1969 at the international conference held the first special-purpose language, ESP (English for Specific Purposes) concept has been proposed. After this concept deepening, its meaning is more profound. When applied to the classroom teaching, it mainly produced two kinds of teaching methods, one is the communicative approach, the second is the content-based teaching method, which is our focus on content-driven teaching model. The teaching method is to emphasize not the language itself, but to experience the language in practice, that is placing the language in the real communication context, rather than the exercise or virtual role-playing teaching, which makes the teaching of language more practical, so that students can better grasp and apply the English language of this common language.

ESP teaching model has provided a direction for college English reform in China, and many scholars have been studying this teaching model. Of course, it has made very good research results. In particular, in August 2011, Professor Cai Jigang of Fudan University gave a lecture on "College English Teaching Content and Teaching Material Development under the Adjustment of Industrial Structure" at the "New Core" Forum College English Teaching and Teaching Materials Seminar, and once again reiterated his views on the direction of the development of college English teaching in China, he believed that the gradual use of ESP teaching model is necessary also should be positioned in such a teaching model. 


\section{The transition of college English teaching from EGP to ESP}

At present we can see that China's general distinction between higher education can be divided into research-oriented colleges and vocational colleges. These two institutions focus on the different aspects of personnel training, one is based on research-based academic talents, the other is to cultivate professional and technical personnel. For these two different types of institutions, the teaching focus of college English courses should also be adjusted accordingly their reality.

In order to research undergraduate institutions, for example, we analyze the ESP teaching in university teaching activities. We all know that undergraduate is four years, from freshman to senior university English learning can be divided into EGP, EGAP, ESAP these stages. ESP stage can be divided into EGAP (General Academic English) and ESAP (professional academic English) the two branches. EGAP teaching is mainly to develop the general academic English skills, ESAP is to require students to familiar with the characteristics of professional English vocabulary, syntax structure and text features, and to do a good job of professional English courses for language preparation.

Just entering the university, freshmen are from all corners of the country in different places and their level of learning is also mixed, so in the latter part of the study will show a different learning curve, which requires teachers to teach students in different grades to solve this difference and requires the students from time to time to do the level of testing, so they can grasp the differences between the students, and then adjust the teaching. This can also be very effective in ensuring the quality of college English teaching.

We all know that all of the set and learning of our high school curriculum is to deal with college entrance examination for the purpose, so the university into ESP teaching, many students are not very adapt to this exchange-oriented teaching. Therefore, teachers in the teaching process should consider English as a teaching tool, focusing on students to do weak listening and speaking, and focusing on strengthening the students in English practical communication.

\section{The main factors restricting the development of ESP teaching}

College English teaching has been gradually reformed to ESP teaching, but the development is still relatively slow and limited to a variety of factors.

First of all, the lack of the correct and comprehensive understanding about ESP teaching. The requirements of "College English Teaching Requirements" promulgated by the State Education Bureau clearly point out that the requirements of college English courses in colleges and universities are mainly to improve the students' English language proficiency and to meet the development needs of students in their respective specialties. Therefore, the college English curriculum should be combined with the development of students and their 
professional content, and cultivate a comprehensive ability and practical application ability. However, the current situation is not optimistic. Although most institutions in accordance with ESP teaching, there are a lot of problems such as only a simple copy and the concept of understanding still stay in the traditional teaching mode. Teaching practicality is not strong, most of which are the lexical explanation, grammar analysis, translation writing, so that the listening and speaking teaching is still not enough for students. Class is centered by explaining of teachers, that is teacher-centered teaching model. Students are still relatively passive acceptance.

Second, the preparation of teaching materials has the lack of practicality. Teaching material is the embodiment of the outline of the process of teaching, the main basis for teachers to carry out teaching activities, and the main carrier of student learning. The importance of teaching materials can be seen. However, many colleges and universities on the selection of the ESP teaching materials go into the two extremes, one is to choose the original foreign textbooks, the other is to use the teacher's own textbook. These two methods are not desirable, on one hand, foreign original textbooks do not have a good combination of our teaching practice, it is difficult for students to understand with the low enthusiasm and efficiency. On the other hand, teachers of self-compiled materials, there is no very clear teaching objectives, most of them only from the professional literature to select the relevant content, but also no matching contact materials, so it lacks practicality. In this way, it is hard for students to improve their level of English. The development of science and technology in the world is rapid, but college English textbooks still remain in the paper textbooks, which no good use of advanced science and technology, to rich diversity of teaching materials.

Finally, ESP teaching faculty should be improved. Teachers are the leaders of teaching activities, ESP teaching also can not do without the teachers, but also for the higher demands of teachers, the need for a more professional level of teaching and more proficient English teaching ability. The teaching level of teachers to a certain extent, restricts the development of ESP teaching activities. ESP teaching is based on students as the starting point, it is necessary to develop students' English language ability, but also to teach students professional and practical application of knowledge. However, at present, college English teachers in China are mainly focus on English teachers or professional teachers, which makes the teacher's knowledge focused only on one hand, the English professional teachers for the professional knowledge of students is not professional, the professional teachers in the English language has been lacking. Both in the knowledge structure are relatively single. Therefore, it is necessary to further improve the professional ESP teaching team.

\section{Methods and strategies of ESP teaching}

Above we briefly analyzed the current teaching of ESP in the shortcomings, then how to solve these problems will become more important thing we should think 
about. Here we will put forward the following aspects to inspire the development of ESP teaching.

First of all, to clarify the curriculum ESP teaching position. Only a comprehensive and profound understanding of ESP teaching and a very accurate positioning, can we do the next step. ESP teaching has high requirements for the professional teachers, the practical ability of students, which is professional, targeted and practical.

Secondly, the development and preparation of professional ESP teaching materials. Not professional teaching materials seriously impact on teaching, so it is necessary to accelerate the preparation of professional ESP teaching and development, and the country should attach importance to the preparation of teaching materials, which should be organized in the field of experts and experienced front-line teaching teachers to work together to prepare a department of Chinese national conditions for the College English textbooks, and to promote the country. Colleges and universities should also be in the amount of teaching materials on the choice of more cautious and in line with the requirements of students. Of course, due to the uneven development of our country, the preparation of teaching materials should be selected in line with the actual situation in the local, to make appropriate adaptation to meet the individual needs of students ESP learning.

Thirdly, to strengthen the training of teachers. Although there are many problems of the ESP teaching, the most to be solved is the teacher problem, because both the preparation of teaching materials, or for the understanding of teaching, are inseparable from the teacher's participation. It can be said that teachers are a key factor that ESP teaching activities can successfully carry out. We can from the following aspects to promote the growth of teachers: First, send some teachers to study abroad. Second, regular invitations of domestic and foreign experts and scholars lectures and the teacher training guidance. Third, teachers can also listen to each other between classes, assessment, exchange of experience, through their own efforts to improve their professional skills and teaching methods.

This is only some small recommendations, ESP teaching needs the country, schools, teachers and students to work together, and only better to promote the healthy and orderly development of ESP courses, to improve the overall level of ESP teaching and to further train professional and practical talents.

\section{Conclusion}

At present, we have a preliminary understanding about he ESP teaching, also recognize its role in college English teaching, but there are still shortcomings, so we need to further study. Therefore, college English teaching can be successfully transferred to ESP teaching mode, that is, from the language-driven model to the content-driven model, which also need to work harder to study and practice. 


\section{References:}

[1] Wang Xiaojing. ESP and College English Teaching Research [J]. Economist, 2015,03; 247-248

[2] Wang Yuliang. Specialized English (ESP) [J]. Journal of Central South University of Forestry \& Technology (Social Science Edition), 2008 (6): 134

[3] Cai Jigang. Globalization of Foreign Language Teaching Tools and Quality of the Significance of the Dispute [J]. Foreign Language, 2010 (6): $33 \sim 40$

[4] Liu Yan, Cai Jigang. An Empirical Study on the Feasibility of the Combination of College English Teaching and ESP Teaching in Independent Colleges [J] .Social Science and Technology, 2009 (12): $161 \sim 162$

[5] Zhang Zhenbang. Also on the Issue of Foreign Language Education in China [J]. Foreign language circles, 2003 (4): $1 \sim 6$

[6] Huang Chengfu. Principles, Teaching Methods and Implementation Approaches of ESP Teaching Ideology in Higher Vocational Colleges [J]. Journal of Chuxiong Normal University (Philosophy and Social Sciences Edition), 2008,12 (6): 64-6. 